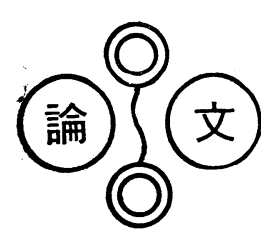

1. 緒言

石炭值接液化の工業化に際しては, 解決すべき問題 点が種々ある。中でも触媒開発が特に重要であり，こ れまでに様々な方からその探索がなされている1 10)。石炭直接液化用触媒を使用形態で大きく分類する と再生利用と使い捨て触媒が考元られる本報告で は, 後者の使用法にかなら使い捨て可能, 即ちディス ポーザブル触媒の探索を目的とした。この種の触媒の 備えるべき性能は，モリブデンなど高価な触媒と同等 の高い活性を有し，短時間反応が可能で生成油が軽沸 点留分に富み, かつ安価で大量に入手可能なことが望 まれる。従来, ディスポーザブル触媒としては鉄系化 合物に関する報告が多く，たとえば第 2 次世界大戦 中, ドイッではアルミニウム製造の際, 副生する赤 泥，沼鉄鉱，硫酸鉄などを実用触媒として用いたこと がある11。

著者らも，このような観点にたち，これまで鉄系触 媒について検討を行ってきたが，現段階では鉄鉱石が 最も有望な液化用ディスポーザブル触媒と考えられ る12)13)。そこで, 種々の鉄鉱石を用い，それらの触媒
性能につて検討したので以下に報告する。なお，鉄鉙 石を触媒として用いた場合，これは反応後，未反応 炭，灰分，特よび液状物質とともに系外に取り出され るのでその固液混合物を蒸留し油分を除いたのち残渣 を乾留し，さらにそのコーライトを製鉄用高炉に粘結

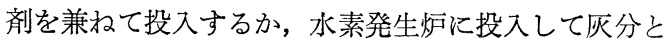
とも渄出する後処理法が考兄られる。

\section{2. 実験}

\section{1 試 料}

実験に用いた石炭は括もに太平洋炭であり，鉄銨石 一硫黄の触媒活性については南大夕張炭もあわせて使 用した。また，高圧示差熱分析ではブキットアッサム 炭を使用した。石炭はボールミルにより 100 mesh 以 下に粉砕し，乾燥後デシケーターに保存し使用した。 Table 1 にその工業分析値拈よび元素分析值を示し た。石炭ペースト用混和油としては水素添加脱晶アン トラセン油を使用したが，この調製法は前報 ${ }^{14)}$ 々同様 である。その元素分析值は C : 91.1 92.6\%, H : 5. 89 6.10\%, H/C : 0.78〜0.79（一）であった。

検討した鉄鉱石は以下の通りである。

Table 1 Analyses of coals

\begin{tabular}{|c|c|c|c|c|c|c|c|c|}
\hline \multirow{2}{*}{ Coal } & \multicolumn{4}{|c|}{ Proximate analysis $(\mathrm{wt} \%)$} & \multicolumn{4}{|c|}{ Ultimate analysis (d.a.f., wt $\%$ ) } \\
\hline & Moisture & $\begin{array}{l}\text { Fixed } \\
\text { carbon }\end{array}$ & $\begin{array}{l}\text { Volatile } \\
\text { matter }\end{array}$ & Ash & $\mathrm{C}$ & $\mathrm{H}$ & $\mathrm{N}$ & $\mathrm{O}^{*}$ \\
\hline Taiheiyo & 5.6 & 35.5 & 47.5 & 11.4 & 77.8 & 5.7 & 1.0 & 15.5 \\
\hline Minamiohyubari & 2.0 & 57.7 & 39.1 & 1.2 & 87.1 & 6.2 & 1.6 & 5.1 \\
\hline Bukit Asam & 10.5 & 42.6 & 45.3 & 1.6 & 72.0 & 5.2 & 0.8 & 22.0 \\
\hline
\end{tabular}

*1第17回石炭科学会議にて一部講演

*2工学部化学工学科 山形県米沢市城南 4

*3森田化学研究所 千葉県八千代市村上3551番地

*4三菱化成工業株式会社 東京都千代田区丸の内 2 三菱ビル

*5三井造船株式会社千葉研究所 千葉県市原市八幡海岸通 1 
Table 2 Analyses of iron ores and red mud

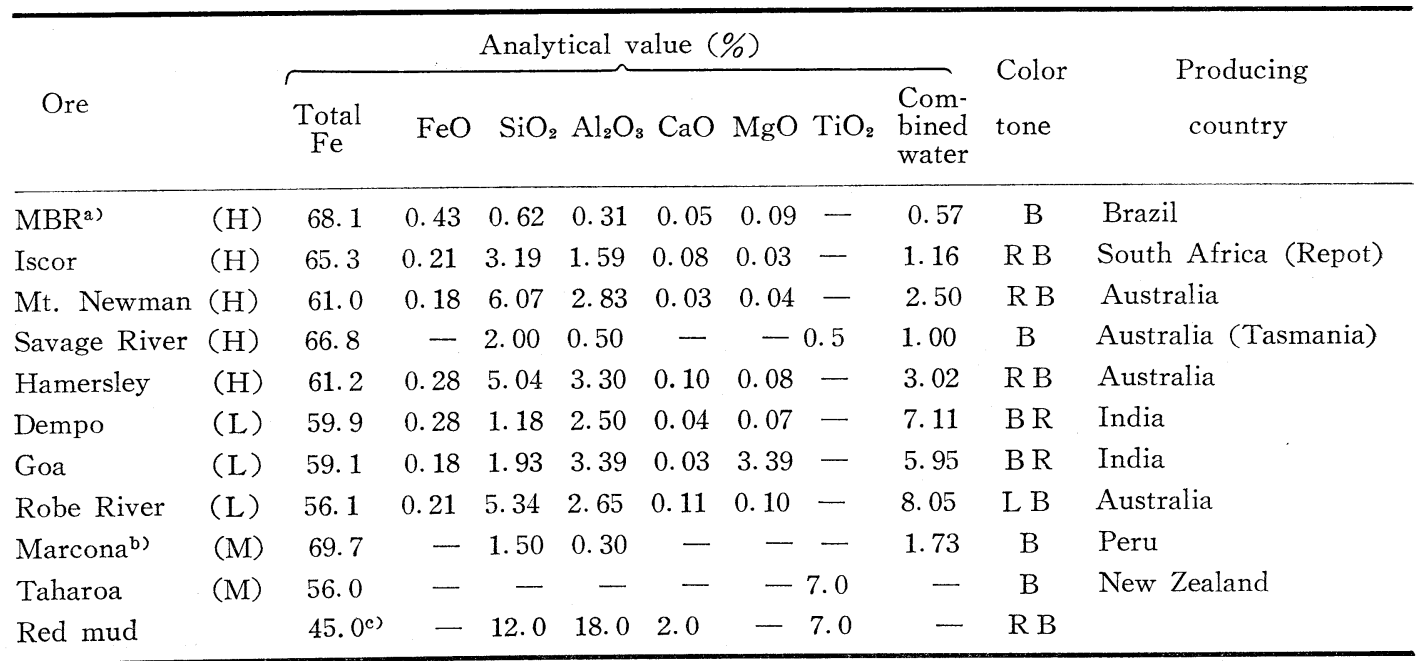

a) Containing a little metallic luster.

b) Received as pellet.

c) $\mathrm{As} \mathrm{Fe}_{2} \mathrm{O}_{3}$

H: Hematite, L: Limonite, M: Magnetite, B: Black, RB: Reddish brown, BR: Brown, LB: Light brown

$\mathrm{MBR}$ 鉱石（赤鉄鉱，ブラジル産）

Iscor 鉱石 (赤鉄鉱, 南アフリカ産)

Mt. Newman 鉱石 (赤鉄鉱, オーストラリア産)

Savage River 鉱石 (赤鉄鉱, オーストラリア産)

Hamersley 鉱石 (赤鉄鉱, オーストラリア産)

Dempo 鉱石（褐鉄鉱，インド産）

Goa 鉱石（褐鉄鉱，インド産）

Robe River 鉱石（褐鉄鉱，オーストラリア産）

Marcona 鉱石 (磁鉄鉱, ペルー産)

Taharoa 鉱石 (砂鉄, ニュージーランド産)

鉄鉱石の触媒性能評価のため, 従来から諸家により 検討されてきた赤泥一硫黄触媒についても実験を行っ た。鉄鉙石, 赤泥はいずれも $200 \mathrm{mesh}$ 以下に粉砕し, 乾燥後デシケーターに保存し使用した。鉄鉱石拉よび 赤泥の分析值を Table 2 に示す。な和以下の記述で は, 鉄鉱石名は単に MBR, Iscor などと記す。

\section{2 装置和よび実験方法}

液化実験は $500 \mathrm{cc}$ と $200 \mathrm{cc}$ の 2 基の回分型振燙式 オートクレーブによって行った。液化生成物の蒸留試 験により液化特性を検討する場合には，比較的多量の 試料を必要とするので $500 \mathrm{cc}$ オートクレーブを，それ 以外では200ccオートクレーブを用いた。 $500 \mathrm{cc}, 200$ cc いずれのオートクレーブも，ほぼ同じ振盪角度士 15度, 振盪数 30 回/分で振盪した。また攪汼球として 前者では径 $18.7 \mathrm{~mm}$, 後者では径 $11.0 \mathrm{~mm}$ の鋼球を 2 個
それぞれ用いた。実験操 作の概略は以下の通りであ る。石炭ペースト（200cc オートクレーブの場合：石 炭 $9.0 \mathrm{~g}$, 混和油 $21.0 \mathrm{~g}$, 触媒所定量。 $500 \mathrm{cc}$ オート クレーブの場合: 石炭 $15.0 \mathrm{~g}$, 混和油 $35.0 \mathrm{~g}$, 触媒所 定量) を反応器に仕込又, 水素初圧 $10.1 \mathrm{MPa}$ (以下 すべてゲージ圧）とし，振盪しながら約 $6.5^{\circ} \mathrm{C} / \mathrm{min} の$ 昇温速度で反応器を加熱し, 設定温度到達後一定時間 （以後これを見掛け反応時間：NRT と称す）反応さ せ，その後 $200^{\circ} \mathrm{C}$ まて振盪しながら自然冷却した。室 温まで冷却後ガスを抜き取り，ガスクロマトグラフィ 一によりガス組成を分析し，液状内容物は n一へキサ ンおよびベンゼン抽出を行い,さらに OBBIS(有機ベン ゼン不溶分) および触媒十灭分の量を求めるためにべ ンゼン抽出残渣の焼成も行い, ガス分 $\left(\mathrm{X}_{\mathrm{Gas}}\right)$, オイル 分 $\left(\mathrm{X}_{\mathrm{Oi1}}\right)$, アスファルテン分 $\left(\mathrm{X}_{\mathrm{Asph}}\right)$ 和よび OBIS (XоBIS) の各組成を定量分析し, 各組成を純炭単位 重量当りで示した。また, 生成物の蒸留試験はASTM -D1160 (原油減圧蒸留法) に準拠し, 10mmHg で 減圧蒸留した。な拈, 触媒添加量は仕込及石炭に対す る重量比（g-cata/g-coal）で表わした。

\section{3. 結果および考察}

\section{1 鉄鉱石一硫黄の触媒活性}

鉄系化合物に硫黄を添加した場合，化合物そのもの のそれより触媒性能が向上すること沾) が知られてい る。そこで, 鉄鉱石に硫黄を添加した系を用い, 比較 
Table 3 Catalytic activities of various iron ores-S and red mud-S

\begin{tabular}{lccccc}
\hline \multirow{2}{*}{ Catalyst } & & \multicolumn{4}{c}{ Composition (-) } \\
\cline { 5 - 6 } & $\mathrm{X}_{\text {Con } \text {. }^{a}}$ & $\mathrm{X}_{\text {Gas }}$ & $\mathrm{X}_{\text {Oi1 }}$ & $\mathrm{X}_{\text {Asph. }}$ & $\mathrm{X}_{\text {OBIS }}$ \\
\hline None & 0.761 & 0.072 & 0.501 & 0.188 & 0.239 \\
MBR-S & 0.854 & 0.081 & 0.635 & 0.138 & 0.146 \\
Iscor-S & 0.885 & 0.026 & 0.677 & 0.182 & 0.115 \\
Mt. Newman-S & 0.880 & 0.076 & 0.729 & 0.075 & 0.120 \\
Savage River-S & 0.885 & 0.108 & 0.704 & 0.073 & 0.115 \\
Hamersley-S & 0.898 & 0.141 & 0.668 & 0.089 & 0.102 \\
Dempo-S & 0.877 & 0.020 & 0.679 & 0.178 & 0.123 \\
Goa-S & 0.878 & 0.017 & 0.694 & 0.167 & 0.122 \\
Robe River-S & 0.918 & 0.044 & 0.798 & 0.076 & 0.082 \\
Marcona-S & 0.862 & 0.048 & 0.739 & 0.075 & 0.138 \\
Taharoa-S & 0.841 & 0.108 & 0.657 & 0.076 & 0.159 \\
Red mud-S & 0.930 & 0.041 & 0.689 & 0.200 & 0.070 \\
\hline
\end{tabular}

a) $\mathrm{X}_{\mathrm{Conv}}=1-\mathrm{X}_{\mathrm{OBIS}}$

Each $0.05 \mathrm{wt}$ ratio of iron ore and sulfur added to the coal Coal: Taiheiyo, React. temp.: $420^{\circ} \mathrm{C}$,

NRT: $10 \mathrm{~min}$

Table 4 Catalytic activities of various iron ores-S and red mud-S

\begin{tabular}{lrcrl}
\hline Catalyst & & \multicolumn{3}{c}{ Composition (-) } \\
\cline { 3 - 6 } & X $_{\text {Conv. }}$ & $\left(\mathrm{X}_{\text {Gas }}+\mathrm{X}_{\text {Oil }}\right)$ & $\mathrm{X}_{\text {A sph. }}$ & $\mathrm{X}_{\text {OBIS }}$ \\
\hline None & 0.510 & 0 & 0.510 & 0.490 \\
MBR-S & 0.783 & 0.496 & 0.314 & 0.217 \\
Savage River-S & 0.730 & 0.386 & 0.344 & 0.270 \\
Robe River-S & 0.717 & 0.377 & 0.340 & 0.283 \\
Taharoa-S & 0.767 & 0.331 & 0.436 & 0.233 \\
Marcona-S & 0.765 & 0.280 & 0.485 & 0.235 \\
Red mud-S & 0.758 & 0.449 & 0.309 & 0.242 \\
\hline
\end{tabular}

Each 0.017 wt ratio of iron ore and sulfur added to the coal Coal: Minamiohyubari, React. temp.: $410^{\circ} \mathrm{C}$, NRT: $10 \mathrm{~min}$

的炭化度の小さい太平洋炭の液化実験を行い，その液 化特性からこの系の活性を検討した。その結果を赤泥 一硫黄触媒の場合とともに Table 3 に示した。なお, 触 媒性能の比較では， $\mathrm{X}_{\mathrm{o} \text { i1 }}$ の值がより大きくかつより小 さい $\mathrm{X}_{\mathrm{OBIS}}, \mathrm{X}_{\mathrm{GAS}}$ を示すものを性能の良好な触媒と 定義した。Table 3によれば, いずれの鉄鉱石とも無 触媒の場合に比較して転化率が10\%以上向上し，かつ この液化条件では全体的にみた場合 赤泥-硫黄触媒 と 同程度, あるいは Rove River-硫黄触媒の場合にはそ れ以上の性能を示すことがわかる。また，太平洋炭よ りも炭化度が高い南大夕張炭を用いて液化実験を行っ た結果を Table 4に示す。これによれぱ, 鉄鉱石一硫

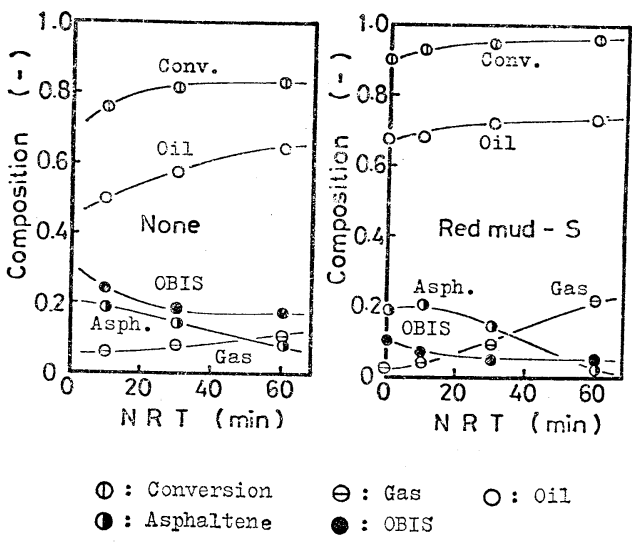

Fig. 1 Liquefaction course of Taiheiyo coal in the absence of catalyst and in the presence of red mud-S catalyst with nominal reaction time (NRT) at reaction temperature $420^{\circ} \mathrm{C}$ and initial hydrogen pressure 10.1 MPa, where red mud and $S$ in the catalyst are contained at weight ratio of 0.05 to the coal

黄系を用いた場合の転化率は赤泥一硫黄触媒の場合の それと同程度であり，炭化度の異なる石炭の液化にお いても, その触媒性能㤸泥一硫黄触媒に匹敵するも のと考光られる。

Figs. 1,2 にはそれぞれ無触媒, 赤泥一硫黄触媒の場 合と赤鉄鉱である MBR, Iscor, 褐鉄鉱である Goa, 

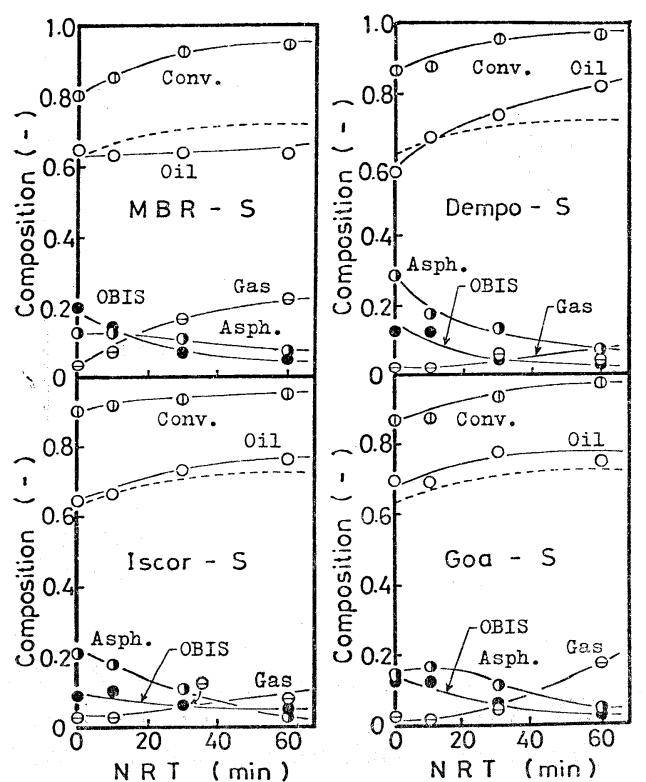

$$
\begin{array}{ll}
0 \text { : Conversion } & \ominus \text { : Gas } 0: 0 i I \\
0 \text { : Asphaltene } & \text { : OBIS }
\end{array}
$$

Fig. 2 Liquefaction course of Taiheiyo coal in the presence of various iron ore-S with nominal reaction time (NRT) at reaction temperature $420^{\circ} \mathrm{C}$ and initial hydrogen pressure 10.1 MPa, where the ores and $\mathrm{S}$ are contained at the same weight ratio as on Fig. 1

Dempo におの拉の硫黄を添加した場合のNRTに対す る液化特性を示した。なお，Fig. 2 の各図中には比 較のため, 同じ条件下で赤泥一硫黄触媒を用いた場合 のオイル分率を点線で示した。これらの結果によれ ば，いずれの場合も NRT の比較的短い $30 \mathrm{~min}$ 以内 で OBIS 分率は 0.1 以下と比較的小さく，また褐鉄 鉱のGoaーおよび Dempo- 硫黄の場合は赤泥一硫黄触 媒に比較して若干高いオイル分率を示している。

Fig. 3 は MBR, Iscor および Goa に硫黄を添加

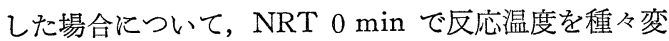
えて得た液化特性の結果である。これによれば，いず れの場合にも反応温度が高くなるに従い明らかに石炭 の分解が進行している。この内, 比較的高い反応温度 域 $430 \sim 450^{\circ} \mathrm{C}$ ではコークスと思われる固形残渣も認 められなかった上に, Table 3 からも解かるようにア スファルテン分率の小さいオイル分に富さ液化生成物 が得られることを示している。

以上の結果から，鉄鉱石一硫黄は赤泥一硫黄触媒を用
いた場合と同程度の液化特性および触媒性能を示すこ とが明らかになった。

\section{2 液化生成物の蒸留試験}

\section{2 .1 液化生成物の蒸留特性}

石炭として太平洋炭を, 触媒として鉄鉱石一硫黄を 用いて液化実験を行った場合の液化生成物の蒸留特性 について検討した。液化生成物は混和油そのものない しはそれからの生成物を含むので, 液化生成物の蒸留 特性を検討する場合には, 混和油のそれすあらかじめ 知って船く必要がある。Fig. 4 に混和油の蒸留曲線 を示す。ここで, 図中，横軸は水分を除いた液化生成 物の体積に対する留出物の体積比 $(\mathrm{V} / \mathrm{V})$ を, 縦軸は 留出温度を示す。Figs.5，6はそれぞれ NRT または 反応温度をパラメータにとり, Iscor および Goa を用 いて得られた液化生成物の蒸留曲線の一例である。乞 れらによると，NRT の増大执よび反応温度が高くな るに従い，蒸留曲線は全体的に右側へ移動する傾向が あり，生成物の軽質化が進行することを示している。

3.2 .2 反応生成物分布

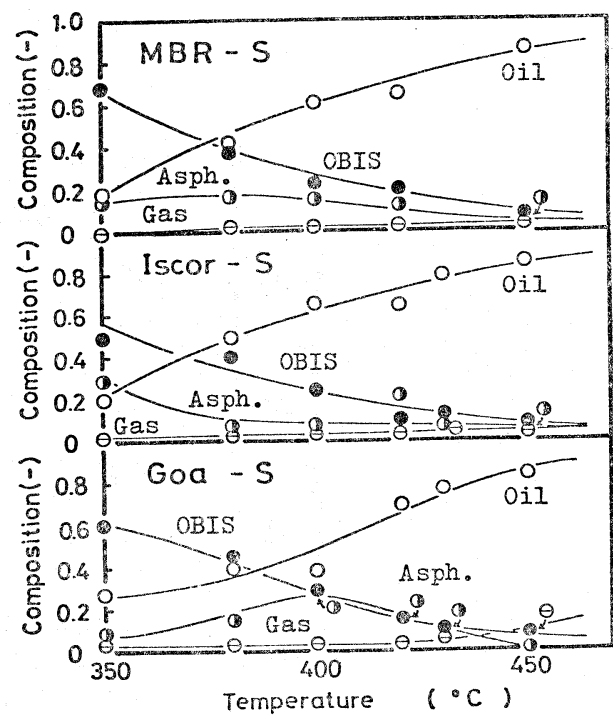

$$
\begin{aligned}
& 0: \text { Gas } 0: 0 i 1 \\
& \text { : Asphaltene : OBIS }
\end{aligned}
$$

Fig. 3 Effect of reaction temperature on product distribution with iron ore-S as catalysts at nominal reaction time (NRT) 0 min and initial hydrogen pressure $10.1 \mathrm{MPa}$, where the ores and $S$ are contained at the same weight ratio as on Fig. 1

(Coal: Taiheiyo) 


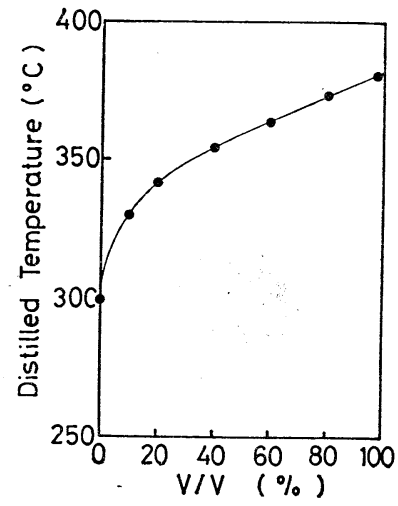

Fig. 4 Distillation of hydrogenated and decrystal anthracene oil

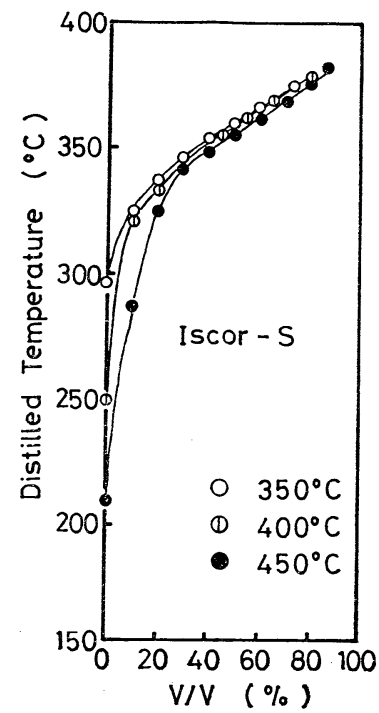

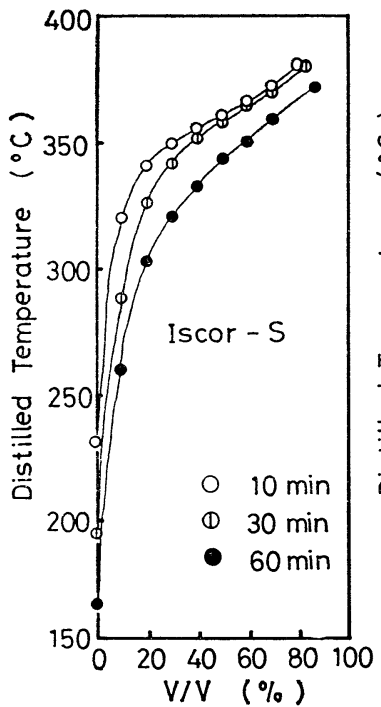

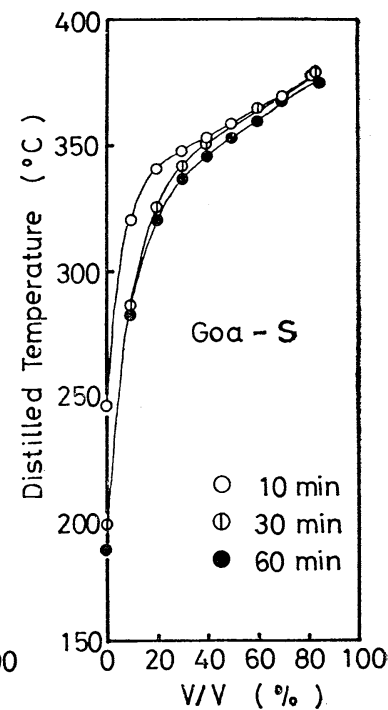

Fig. 5 Distillation of liquefaction products from Taiheiyo coal in the presence of Iscor ore-S and Goa ore-S catalysts with nominal reaction time (NRT) at reaction temperature $420^{\circ} \mathrm{C}$ and initial hydrogen pressure 10.1 $M P a$, where the ores and $S$ are containd at the same weight ratio as on Fig. 1

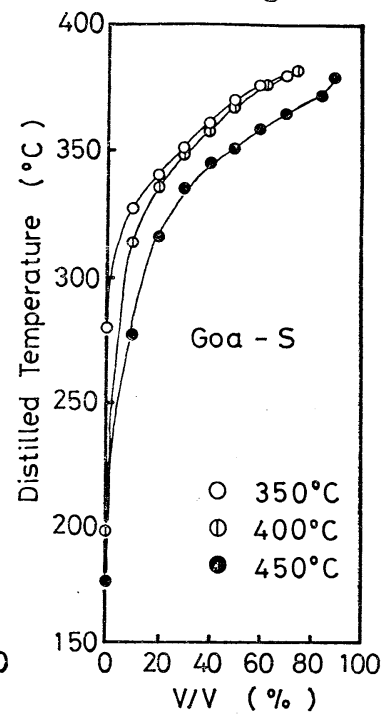

Fig. 6 Distillation of liquefaction products of Taiheiyo coal in the presence of Iscor ore-S and Goa ore-S catalysts with reaction temperature at nominal reaction time (NRT) 0 min and initial hydrogen pressure $10.1 \mathrm{MPa}$, where the ores and $\mathrm{S}$ are contained at the same weight ratio as on Fig. 1

石炭として太平洋炭を用い鉄鉱石一硫黄叔よび赤泥一 硫黄触媒の触媒性能を蒸留試験により得られる反応生 成物の分布から比較検討した。以下の検討は反応温度 $420^{\circ} \mathrm{C}$, NRT $10 \mathrm{~min}$ の一定条件で行ったものであり,
反応生成物分布は純炭基準で示す。結果の一例をFig. 7 に示した。ここで成分として IBP (初留) $250^{\circ} \mathrm{C}$ 留 分, $250 \sim 330^{\circ} \mathrm{C}$ 留分, $330 \sim 380^{\circ} \mathrm{C}$ 留分特よび $380^{\circ} \mathrm{C}$ 以 上の蒸留釜残分の 4 成分に分割し，その量は伊藤ら ${ }^{18)}$ 


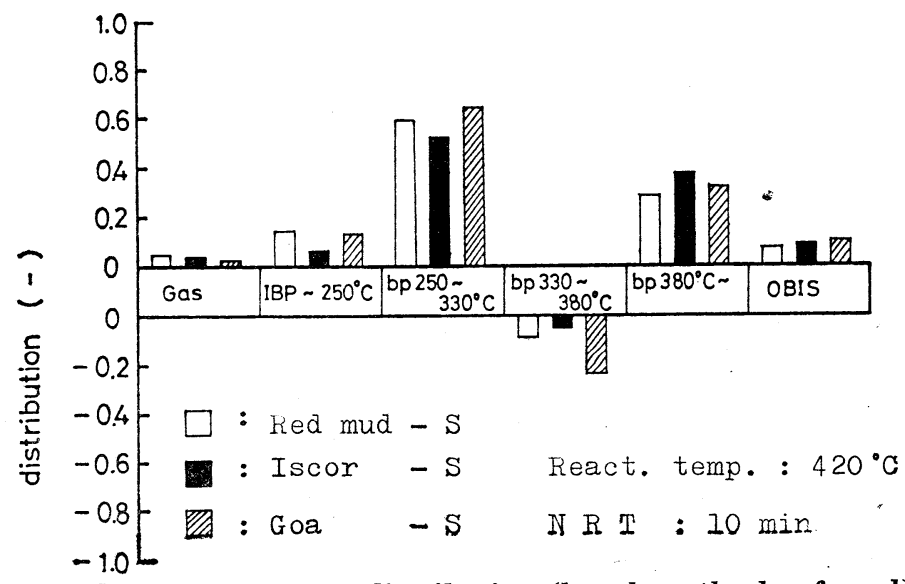

Fig. 7 Effect of catalyst on component distribution (based on the d.a.f. coal) for Taiheiyo coal liquefaction at initial hydrogen pressure $10.1 \mathrm{MPa}$

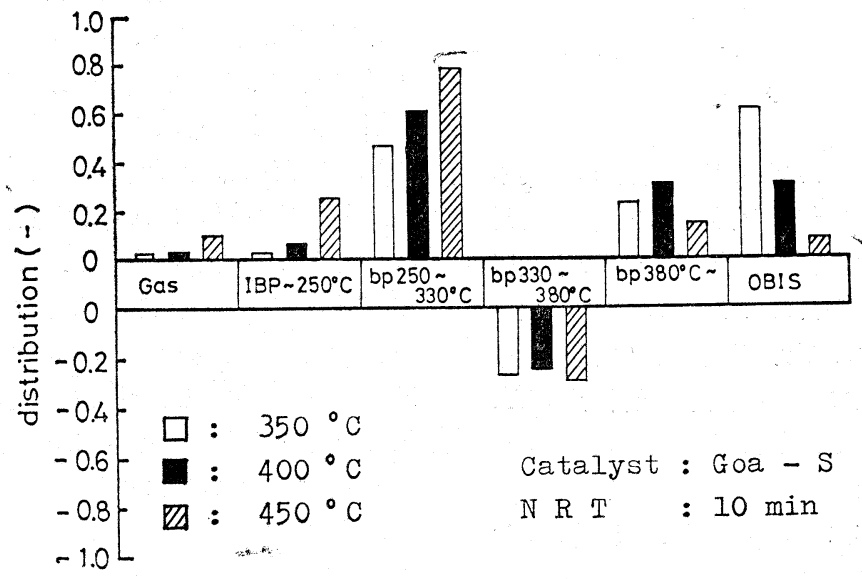

Fig. 8 Effect of reaction temperature on component distribution (based on the d.a.f. coal) for Taiheiyo coal liquefaction under the influence of Goa ore-S catalyst at initial hydrogen pressure 10.1 $\mathrm{MPa}$

が求めたように, 蒸留試験取得各成分量から混和油の 対応する成分量を差し引いた值を純炭換算して求めた ものである。Fig.7に打いて, 赤泥一硫黄触媒, Iscor扣よび Goa-硫黄はいずれも転化率が約 0.9 と同程度 であり，反応生成物分布もほぼ同様の傾向を示してい る。また，この条件下ではいずれの場合も沸点 250〜 $330^{\circ} \mathrm{C}$ の中・軽油留分が最も大きな割合を占めている ことがわかる。な拈，330 $380^{\circ}$ C 留分が負の值を示し ているが，これはこの成分量の大部分を占める水素添 加脱晶アントラセン油が液化進行に伴って軽質化ある いは重縮合することにより，その一部が他の成分へ変 化したためか，または共沸混合物の生成によるものと 考えられる。このような結果は, 伊藤ら ${ }^{16)}$, 吉田ら ${ }^{17)}$
によるヤルーン炭の液化実験に特いても認められてい る。

Fig. 8 に Goa-硫黄系で反応温度を変化させた場合 の反応生成物分布を示した。これによると, 反応温度 の増大とともにガス分, IBP $250^{\circ} \mathrm{C}$ 留分, $250 \sim 330$ ${ }^{\circ} \mathrm{C}$ 留分の増加, 未反応炭 (OBIS) の減少する傾向, さらに, 沸点 $380^{\circ} \mathrm{C}$ 以上のアスファルテン分に富むと 考えられる成分量が反応温度 $400^{\circ} \mathrm{C}$ で極大值を示すこ とがわかる。

このような蒸留特性によっても，鉄 鉱石一硫黄は, 現在のところ有望とみられている赤泥一硫黄触媒と同 程度あるいはそれ以上の触媒性能を示して和り, 十分 実用触媒として使用できるものと思われる。 


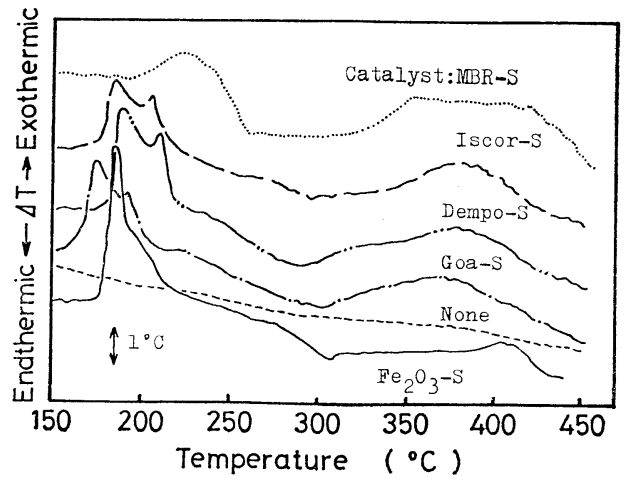

Coal : Bukit Asam, Fe/Coal (d.a.f.) : 0.60 (weight ratio), $\mathrm{S} / \mathrm{Fe}: 0.75$ (atomic ratio), Reaction temperature : up to $460^{\circ} \mathrm{C}$, Initial hydrogen pressure $: 20.3 \mathrm{MPa}$, Heating rate: $5.0^{\circ} \mathrm{C} / \mathrm{min}$

Fig. 9 Differentia thermograms of hydrogenation of Bukit Asam coal with various iron ores-S and $\mathrm{Fe}_{2} \mathrm{O}_{3}-\mathrm{S}$ catalysts

\section{3 触媒の形態変化}

石炭水素化分解反応過 程に括汀る鉄鉱石一硫黄系の 作用機構に関する基礎的な知見を得るため，分解また は反応に伴う熱的変化を高圧示差熱分析 (DTA) 装置 により測定しまたX線回折により触媒の形態変化を 追跡した。测定装置および方法は既報 ${ }^{18)}$ と同様であ り, DTA より得られたピークの前後で試料を DTA 装置からすばやく取り出し，それぞれX線回折により それらの物質を同定した。

3.3.1 鉄鉣石一硫黄による石炭の高圧水添反忘に括 ける DTA
試料炭としてブキットアッサム炭を使用し，鉄鉱石 に硫黄を添加した系による高圧水添反応の DTA 曲線 の一例を Fig. 9 に示した。また, 比較のため無触媒 および市販 $\mathrm{Fe}_{2} \mathrm{O}_{3}$ に硫黄を添加した触媒で得られた DTA 曲線も示した。いずれも $\mathrm{S} / \mathrm{Fe}$ (原子比) $=0.75$ として添加した。本実験条件に特いて, 無触媒の場合 にはピークの発生がほとんど認められないのに対し て, 上記のものを添加した場合にはピークが発生して 特り, 明らかに触媒添加の影響が認められる。Iscọ, Dempo, Goa および $\mathrm{Fe}_{2} \mathrm{O}_{3}$ にそれぞれ硫黄を添加し たものを使用した場合にはいずれも $200^{\circ} \mathrm{C}$ 付近に $2 つ$ の発熱ピークが見られ，かつ類似の DTA 曲線が得ら れた。MBR-硫黄についてはやはり前者らと同様の発 熱ピークが見られるものの, ピーク温度が高温側にず れ，かつ前者らの場合と比較してやや異なったピーク 形状を示している。また，いずれの鉄鉱石一硫黄でも 石井ら”が報告している $350 \sim 420^{\circ} \mathrm{C}$ の石炭水添反応に 相当する発熱ピークが見られ，DTA 曲線からもとの 触媒効果が認められる。

3.3 .2 高圧水素雲团気に打ける鉄鉱石-硫黄のDTA 高圧水素雲囲気に扣いて 鉄鉱石一硫黄の形態変化を 検討するため，代表例として Iscor を，また比較のた め市販 $\mathrm{Fe}_{2} \mathrm{O}_{3}$ を使用し，それぞれに硫黄を添加した 場合の DTA 曲線を Fig. 10 に示した。な特，各温 度でサンプリングした試料の常温に拈けるX線回折結 果を一括して Figs. 11, 12 に示した。 $\mathrm{Fe}_{2} \mathrm{O}_{3}$ 一硫黄触媒 の場合, $120^{\circ} \mathrm{C}$ 付近に硫黄の融解によるものと考舜ら れる吸熱ピークが見られ，また $220^{\circ} \mathrm{C}$ 付近には $2 つ の ~$ 大きな発熱ピークが認められた。 $220^{\circ} \mathrm{C}$ 付近に和ける

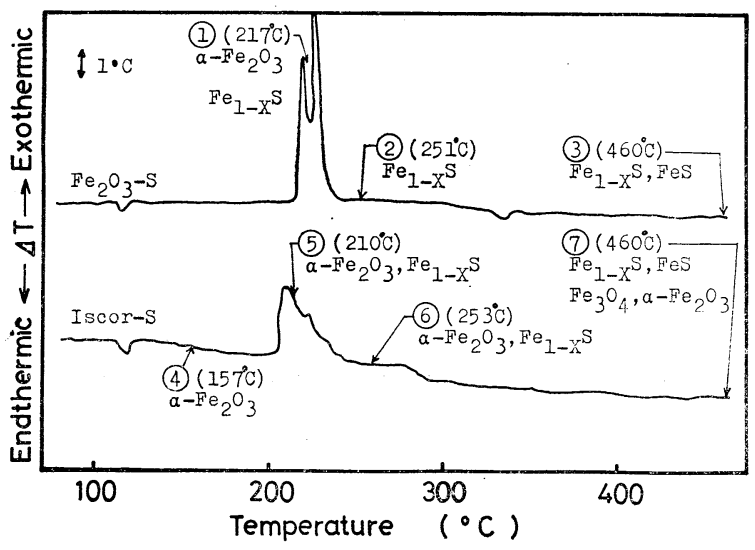

Experimental conditions are the same as those shown in Fig. 9

Fig. 10 Differential thermograms of $\mathrm{Fe}_{2} \mathrm{O}_{3}-\mathrm{S}$ and Iscor ore-S in hydrogen, and identified materials by $\mathrm{X}$-ray diffraction pattern analysis shown in the following figure 


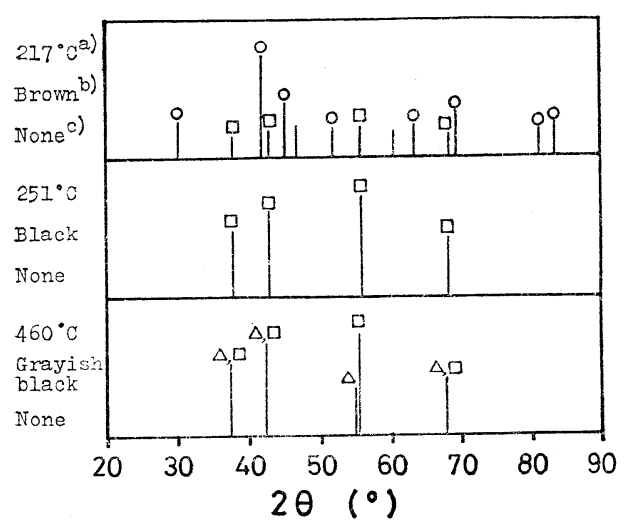

Radiation : $\mathrm{Fe}-\mathrm{K} \alpha$, Filter : $\mathrm{Mn}$

$\mathrm{O}: \alpha-\mathrm{Fe}_{2} \mathrm{O}_{3}$ (ASTM13-534), $\square: \mathrm{Fe}_{1-\mathrm{xS}}$ (JCPDS 29-724), $\triangle$ : FeS (JCPDS 24-80A)

a ) Temperature of sampling, b ) Color tone of sample, c) Magnetism of sample

Fig. $11 \mathrm{X}$-ray diffraction pattern of a mixture of $\mathrm{Fe}_{2} \mathrm{O}_{3}$ with $\mathrm{S}$

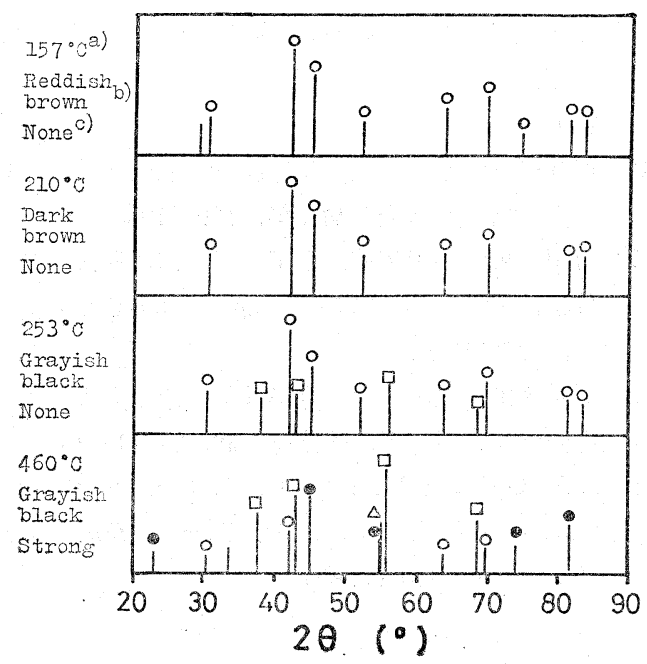

Radiation : Fe-K $\alpha$, Filter : Mn

$\mathrm{O}: \alpha-\mathrm{Fe}_{2} \mathrm{O}_{3}$ (ASTM 13-534), $\square: \mathrm{Fe}_{1-\mathrm{xS}}$ (JCPDS 29-724), $\triangle:$ FeS (JCPDS 24-80A),

- $\mathrm{Fe}_{3} \mathrm{O}_{4}$ (ASTM 19-629)

a) Temperature of sampling, b) Color tone of sample, c) Magnetism of sample

Fig. $12 \mathrm{X}$-ray diffraction pattern of a mixture of Iscor ore with $\mathrm{S}$

それぞれのピーク後の試料（1，(2)）をX線回折し た。それによれば，初めのピーク後試料(1)その大部 分が $\alpha-\mathrm{Fe}_{2} \mathrm{O}_{3}$ で岗り，その他に若干の不定比硫化鉄 $\mathrm{Fe}_{1-\mathrm{x}} \mathrm{S}$ を含むことがわかった。また廃がス中に硫化
水素が検出されたことから, 初めのピークは硫化水素 生成による発熱ピークと考兄られる。また，X線回折 より，後のピーク後試料(2) その注とんどが $\mathrm{Fe}_{1-\mathrm{x}} \mathrm{S}$ であることがわかったので，後のピークは硫化水素と $\mathrm{Fe}_{2} \mathrm{O}_{3}$ の反応汇っって $\mathrm{Fe}_{1-\mathrm{x}} \mathrm{S}$ が生成する際の発熱ピ ークと推定される。 $330^{\circ} \mathrm{C}$ 亿和汀る小さな吸熱ピーク がどのよらな変化に対応するかは不明である。以上, 高圧水素雾团気に扮いては, $\mathrm{Fe}_{2} \mathrm{O}_{3}$-硫黄触媒は $250^{\circ} \mathrm{C}$ 付近までに不定比硫化鉄 $\mathrm{Fe}_{1-\mathrm{xS}} \mathrm{S}$ 形態変化すること， $250^{\circ} \mathrm{C}$ 以後, $330^{\circ} \mathrm{C}$ 付近の生成水の蒸発に上る吸熱ピー クを除いてその DTA 曲線に特別な変化が認められな いことにより，不定比硫化鉄 ${ }^{*} \mathrm{Fe}_{1-\mathrm{x}} \mathrm{S}$ が石炭水添触媒 として作用を示するのと推測される。Guin ら ${ }^{19)}$ 石硫 化鉄触媒によるベンン゙チオフェンの水素添加反応にお いて同様のことを報:告汭ている。しかし，試料(2)と $460^{\circ} \mathrm{C}$ まで昇温し得た試料(3)を比較した場合，色調が 黒色から灰黑色湾化して敊り，X線回折の結果より $\mathrm{Fe}_{1-\mathrm{x}} \mathrm{S}$ の他に $2 \theta=55.0^{\circ}$ 飞定比硫化鉄 $\mathrm{FeS}$ の回折 ピーク $\left(\mathrm{Fe}_{1-\mathrm{xS}}\right.$ と $\mathrm{FeS}$ の $2 \theta=37.5^{\circ}, 42.5^{\circ}, 68.2^{\circ}$ の回折ピークは重さなっていると考穴られる) が認め られ，高温になると $\mathrm{Fe}_{1-\mathrm{x}} \mathrm{S}$ はしだいに硫化が進行 乙，定比硫化鉄 $\mathrm{FeS}$ になるものと思われる。

次に, Iscor-硫黄の DTA 曲線の場合, $120^{\circ} \mathrm{C}$ に夕 られる吸熱ピークは硫黄の融解によるるのであり, 200 250 $\mathrm{C}$ の発熱ピークは $\mathrm{Fe}_{2} \mathrm{O}_{3}$-硫黄触媒の場合と 同様のピークと考兄られる。また， $253^{\circ} \mathrm{C}$ の発熱ピー ク直後の試料(6)と $460^{\circ} \mathrm{C}$ まで昇温し得た試料(7)のX線 回折結果と色調和よび磁性の有無から， $253^{\circ} \mathrm{C}$ の試料 (6)中には $\alpha-\mathrm{Fe}_{2} \mathrm{O}_{3}$ と $\mathrm{Fe}_{1-\mathrm{x}} \mathrm{S}$ が, $460^{\circ} \mathrm{C}$ の試料(7)中に は $\alpha-\mathrm{Fe}_{2} \mathrm{O}_{3}, \mathrm{Fe}_{1-\mathrm{x}} \mathrm{S}, \mathrm{FeS}$ 特よび $\mathrm{Fe}_{3} \mathrm{O}_{4}$ が存在する ものと考光られる。従って, Iscor-硫黄の高圧水素雾 囲気に拈惊る反応過程は Iscor の主成分が $\mathrm{Fe}_{2} \mathrm{O}_{3}$ で あることから，先に述べた $\mathrm{Fe}_{2} \mathrm{O}_{3}$ と本質的に变わら ないものと考兄られる。しかしながら， $\mathrm{Fe}_{2} \mathrm{O}_{3}$ では $250^{\circ} \mathrm{C}$ 前後でそのほとんどが $\mathrm{Fe}_{1-\mathrm{x}} \mathrm{S}$ に変化し， 460 ${ }^{\circ} \mathrm{C}$ ではさらに硫化が進行しているのに対し，Iscor で は $460^{\circ} \mathrm{C}$ まで昇温し得た試料(7)中に未反応の $\alpha-\mathrm{Fe}_{2} \mathrm{O}_{3}$ が存在していた。これは，天然物である鉄鉱石が市販 $\mathrm{Fe}_{2} \mathrm{O}_{3}$ 亿比較して, 内部の気孔がきわ微細でかっ その量も少なく非多孔性構造を有するものと考光ら れ, そのため硫化水素との有効接触面積が小さく, $\mathrm{Fe}_{1-\mathrm{x}} \mathrm{S}$ への転化反応速度が荤いため, $460^{\circ} \mathrm{C}$ の昇温 時まで $\mathrm{Fe}_{2} \mathrm{O}_{3}$ として残存するものがあるためと考光 られる。以上のことより, 鉄鉱石の触媒性能をより有 効に作用させるためには, 鉱石粒子をきわめて細くし 
触媒有効面積を増大することが望まれ，鉄鉱石の粒度 抢よび比表面積とその活性に及ぼす影響について検討 する必要がある。

\section{4. 結 論}

(1) 見掛け反応時間が短く, 反応温度 $420^{\circ} \mathrm{C}$ の比較 的稳和な反応 条件下で, 鉄鉱石一硫黄系触媒は赤泥触 媒と同程度あるいはそれ以上の性能を有し、ディスポ 一ザブル触媒として十分使用可能と考㝋られる。

（2）液化生成物の蒸留試験の結果，鉄鉱石一硫黄は 赤泥一硫黄触媒の場合と同様な反応生成物分布を示し, からその生成物分布中 $250 \sim 330^{\circ} \mathrm{C}$ の中・軽油留分が大 きな割合を占めた。

（3）高圧示差熱分析の結果，赤鉄鉱拈よび褐鉄鉱に 硫黄を添加した場合の作 用機構は $\mathrm{Fe}_{2} \mathrm{O}_{3}$-硫黄触媒の それと同様で, 活性中心は不定比硫化鉄 $\mathrm{Fe}_{1-\mathrm{xS}}$ と考 えられる。

本研究を行らにあたり, 石炭試料, 鉄鉱石和よび赤 泥を提供下さった太平洋炭礦株式会社, 三菱石炭釷業 株式会社南大夕張礦業所, 新日本製鉄株式会社, 日本 軽金属株式会社苫小牧工場, X線回折分析に協力いた だいた東北大学金属材料研究所ならびに鉄鉱石に関し 鉱物学的な立場から助言をいただいた本学理学部の大 町北一郎教授に対し厚く謝意を表します。な敊, 本研 究の一部は, 通産省工業技術院サンシャイン計画推進 本部の研究費によった。

\section{文献}

1) 阿部良之助, 藤川博康, 角谷忠次郎, 岡村 保, 杉山邦一, 工化, 41，862 (1938)

2) 熊谷直記, “硬化油”, 触媒化学シリーズ, 尚賢堂 (1938)

3）黑川真武, 工化，45，1030（1942）

4）黑川真武, 工化, 46, 535 (1943)

5) S.Weller, M. G. Pelipetz, S. Friedman, H.H.
Storch, Ind. Eng. Chem., 42, 330 (1950)

6) 石井忠雄, 真田祐治, 武谷 愿, 工化, 71, 1783 (1968)

7) 石井忠雄, 真田祐治, 武谷 愿, 工化, 72, 1269 (1969)

8) 伊藤博徳, 牧野和夫, 梅田憲章, 武谷 愿, 上田 成, 然協誌，50，919（1971）

9 ）上田 成, 前河涌典, 石井忠雄, 武谷 愿, 燃協 誌, 50, 938 (1971)

10）森田 穣, 佐藤志美雄, 橋本孝雄, 丹羽龍史, 志 布恵司，燃協誌，57，980 (1978)

11) H. Buchholz-Meisenheimer, "Ullmanns Encycklopadie der Tech. Chemie.”, 10, 488(1958)

12）豊沜弘幸, 佐藤志美雄, 橋本孝雄, 森田穣 ，第 16回石炭科学会議論文集, 118 (1979)

13）森田 穣, 橋本孝雄, 佐藤志美雄, 豊嶋弘幸, 伊 藤敏雄, 日化, 931 (1980)

14）森田 穣, 佐藤志美雄, 橋本孝雄, 原 祥夫, 燃 協誌，59，314（1980）

15) . 宗像英二, “化学研究の開発技術について”（朝鮮 窒素阿吾地工場に 和汀る石炭液化工業の研究開 発)

16）伊藤秀伸, 原 祥夫, 村田勝英, 北岡洋治, 第17 回石炭科学会議発表論文集, 130 (1980)

17）吉田 忠, 中田善徳, 上田 成, 前河涌典, 神田 伸靖, 三枝 等, 第 17 回石炭科 学 会議発表論文 集, 137 (1980)

18）橋本孝雄, 豊嶋弘幸, 今泉武男, 池添光則, 佐藤 志美雄, 森田 穣, 燃協誌, 60, 21 (1981)

19) J. A. Guin, J. M. Lee, C.W. Fan, C.W. Curtis, J. L. Lloyd, A. R. Tarrer, Ind. Eng. Chem., 19, 440 (1980) 


\title{
Catalytic Activities of Iron Ores in Direct Liquefaction of Coal
}

\author{
Minoru Morita, Mitsunori Ikezoe, Takao Hashimoto, \\ Shimio SATo, Takeo IMAIZUMI and Hiroyuki NiHEI
}

(Faculty of Engineering, Yamagata University)

SYNOPSIS : - Catalytic activities of various iron ores, hematite, limonite and magnetite, mixed with sulfur were examined in order to develop a disposable catalyst in direct liquefaction of coal. A catalytic mechanism of them was investigated with differential thermal analysis and X-ray diffraction analysis.

The following results were obtained; (1) Most of them were as active as or more active than red mud mixed with sulfur, which has been regarded as the catalyst, even under relatively mild liquefaction conditions and liquefaction products under the influence of them were rich in middle and light oils. Thus they are expected to become one of the catalysts; (2) The catalytic mechanism in the presence of them, except for magnetite, was supposed to be similar to that of $\mathrm{Fe}_{2} \mathrm{O}_{3}$ mixed with sulfur. 